\title{
COMPARATIVE TrafFic SAFETy STUDY IN FEDERATION OF BOSNIA AND HERZEGOVINA, REPUBLIC OF SRPSKA, BRCKO DISTRICT AND EU COUNTRIES USING DATA ENVELOPMENT ANALYSIS
}

\author{
Hadis Bajric, Edin Kadric, Mugdim Pasic, Izet Bijelonja, Ajdin Vatres, \\ Mirza Pasic, Adnan Tatarevic \& Birsen Eljazovic
}
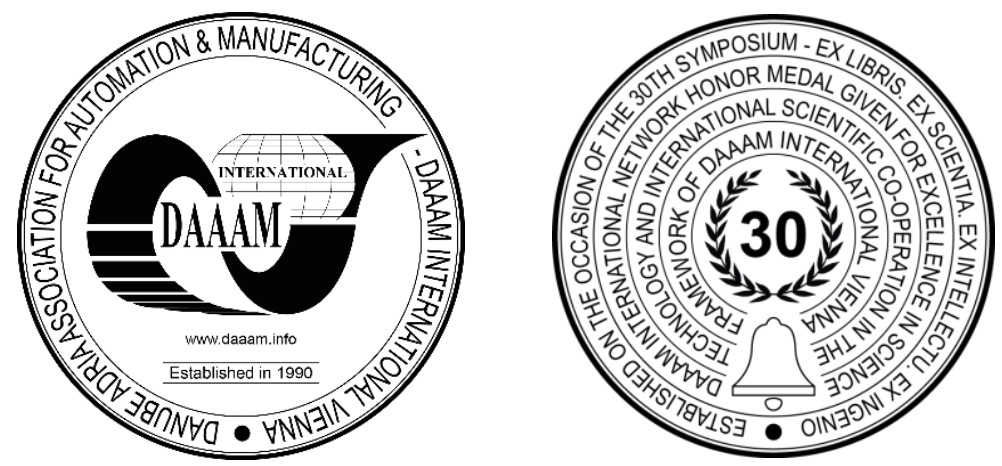

This Publication has to be referred as: Bajric, H[adis]; Kadric, E[din]; Pasic, M[ugdim]; Bijelonja, I[zet]; Vatres, A[jdin] \& Pasic, M[irza] (2019). Comparative Traffic Safety Study in Federation of Bosnia and Herzegovina, Republic of Srpska, Brcko District and EU Countries Using Data Envelopment Analysis, Proceedings of the 30th DAAAM International Symposium, pp.0107-0114, B. Katalinic (Ed.), Published by DAAAM International, ISBN 978-3-90273422-8, ISSN 1726-9679, Vienna, Austria

DOI: $10.2507 / 30$ th.daaam.proceedings.014

\begin{abstract}
This paper deals with the survey and assessment of traffic safety in Federation of Bosnia and Herzegovina (F B\&H) and compares it to the traffic safety in Republic of Srpska (RS), Brcko District (BD) and EU countries. The assessment and comparison of traffic safety in this study is based on data collected from various referential statistical sources, the same being related to the period 2015-2016. For the analysis, a Data Envelopment Analysis (DEA) method has been selected, which enables a comparative assessment of the traffic safety of certain regions (cities, cantons, states) based on multiple indicators, such as number of traffic accidents, number of deaths, number of seriously injured compared to the number of inhabitants, road lengths, etc. DEA, as an objective and nonparametric method, does not favor any of the selected criteria, but provides equal chances to all units whose performances are being evaluated.

Paper gives a brief theoretical overview of DEA method, brief survey of literature related to application of DEA method in analysis of traffic safety, data and sources of collected data, as well as developed DEA model. Conducted analysis enabled estimation of traffic safety efficacy, identification of countries/entities/districts with traffic safety not at the level of the relatively most secure countries, and estimation of possible improvements related to reduction of the total number of traffic accidents and number of people died in traffic accidents, for all countries/entities/districts.

Based on the conducted analysis it can be concluded that there is a significant difference in the efficiency of traffic safety in EU countries. At the level of all EU countries, including B\&H (F B\&H, RS and BD), the total number of traffic accidents can be reduced by $458.142,9$ or by $42 \%$ per year, while the total number of people died can be reduced by $10.674,42$ or by $38 \%$ per year. The analysis has shown that the highest level of traffic safety is in Denmark, Finland, the Netherlands and Sweden, while traffic safety is the lowest in F B\&H, Romania, RS and BD.
\end{abstract}

Keywords: DEA; traffic safety; B\&H; EU countries. 


\section{Introduction}

Globally, traffic accidents are the leading cause of death among young people and the main cause of death among people aged 15 to 29. Furthermore, estimates indicate that traffic accidents are the ninth leading cause of death in all age groups worldwide and will become the seventh leading cause of deaths by 2030 . This growth was triggered by escalating the number of died in traffic accidents, in low and middle income countries, particularly in emerging economies, where urbanization and motorization follows rapid economic growth. Every year, more than 1,2 million people die in traffic accidents worldwide, and millions of people live with serious injuries and long-term adverse health effects. Namely, up to 50 million people suffer from non-fatal consequences of traffic accidents each year, and additional indirect health consequences, associated with this growing epidemic, need to be taken into account. Injuries resulted from traffic accidents represent a burden both for national economies as well as for individual households, and in low and middle income countries, they have strong impact on an economically active age group. Because of the loss of a breadwinner, or the cost of long-term medical care for a family member, many families have been pushed into poverty, while at the state level, costs in the healthcare, legal and insurance sector are enormous, which is particularly evident in countries where the level of investment in traffic safety is not kept up with the size of the problem. Data show that deaths and injuries caused by traffic accidents, in low and middle income countries, cause losses of up to 5\% of GDP, while globally these losses are around $3 \%$ of GDP [1].

Road transport accounts for $88 \%$ of total EU passenger transport, but $97 \%$ of all traffic deaths in the EU are caused by road traffic. It is hundred times more deaths in road traffic than in all other modes of transport [2]. The ETSC (European Transport Safety Council) estimates that the cash equivalent of the benefits of preventing human losses to society is $€ 1.7$ million per one death (by factor cost adjusted to prices in 2009., buying power and GDP) [3].

Bearing the foregoing in mind, it is necessary to monitor and implement strategies at national level in order to improve road safety. In order to assess the success of the implemented programs and reforms, it is necessary to conduct comprehensive analysis and compare with others, and when possible enable transfer of the knowledge, experience and best practices.

Traffic safety is a permanent task of each country and region, which is realized through the relevant ministries, state agencies and institutions. The starting point in traffic safety management is the assessment of traffic safety and its comparison to traffic safety in other regions (municipalities, cantons, entities, states). As traffic safety cannot be expressed by one absolute indicator, different, mostly relative, safety measures have been developed.

The most well-known direct relative indicators of traffic safety are: public risk (number of died in relation to total population), traffic risk (number of died in relation to number of registered vehicles) and dynamic risk (number of died in relation to number of kilometers) [4, 5]. Application of these indicators gives good estimates of traffic, but only in certain segments, so the issue of comprehensive traffic safety assessment, that could be used for a comparative assessment of traffic safety of different territorial units/regions (cities, cantons, entities, states) still remains.

In addition to traffic safety indicators at the level of a given geographic area, there are also methodologies for assessing the safety of the road sections. One of the most important and generally accepted global programs and methodologies for road safety assessment is the EuroRAP (European Road Assessment Program). EuroRAP has been accepted by most EU countries. The lack of the EuroRAP methodology is use of a parametric approach for assessment of different safety indicators. This leads to non-objective traffic safety estimates, since the weights for each of the indicators are predetermined in advance.

One of the newer methods for evaluation and objective comparison of multi-criteria problems (multiple input variables and/or multiple output variables) is Data Envelopment Analysis (DEA). The DEA method is based on linear mathematical programming and enables quantification of the relative efficiency of each decision making unit (DMU).

The use of the DEA method in the assessment of traffic safety is presented in a large number of scientific papers, and most studies are predominantly concerned with the security than the efficiency of the used/available resources. Significance of the DEA method in assessment of traffic efficiency (traffic safety) is an important tool recognized in the document "Developing a Road Safety Index", which is Deliverable 4.9 of the European Commission, and part of the DaCoT project [6]. The authors of [5] emphasize that the DEA method, due to its multi-criteria and nonparametric characteristics, is extremely suitable for assessment of traffic safety. Particularly emphasizing that the power of the DEA method lies not in the fact of rating, but in comparison with the examples of the best practices. 


\section{Literature review}

The DEA method is widely used to analyze and evaluate efficiency in many different fields, especially in the public services sector and non-profit organizations [7]. There are numerous scientific papers in which DEA methods are used for the assessment of traffic safety. DEA method is used in [8] to provide technical support to policy makers by comparing the performance of different urban networks with the choice of measures to be implemented in order to make city road systems effective.

In [9] DEA method is used for analysis of a homogeneous group of 22 Turkish airports, which are also accredited as "handicap friendly" and "green" airports. The specificity of the study was the appearance of unwanted outputs, such as gas emissions. The research approach presented in [10] allowed the ranking of 13 Czech regions according to their road safety, based on composite indicators. Using data on socio-economic losses for 2014, the authors investigated four approaches to define indicators: principal component analysis, factor analysis, rank sum ratio method and DEA method. The final ranking result is a combination of all four approaches.

Based on the DEA method, a model of the Malmquist index was developed in the study [11] to assess the relative efficiency and productivity of US states in reduction of number of died on the roads. The analysis encompassed 50 US states in the period 2002-2008, and the model itself is based on one output (a deadly case scenario) and five aggregated inputs, conjoined into a unique security score.

To evaluate the efficiency of the 27 police administrations in the Republic of Serbia, DEA model with two input and three output parameters was used [4]. The input parameters were the number of inhabitants and the number of registered motor vehicles, while the output represented the number of persons died in traffic accidents, the number of seriously injured persons and the number of easily injured persons. The analysis is based on the basic DEA model, where the assessment of the efficiency is gained through the matrix of mutual efficacy, and these values are compared to each other afterwards.

In [12] the DEA method was applied for analysis of the overall road safety performance in 27 EU countries. Three extensions of the DEA model were applied: DEA-RS, method of mutual efficacy, and categorical DEA model. Number of died has been selected as output variable. In addition, cluster analysis was used to group countries with inherent similarity in their behavior and management. This approach enabled identification of the best and worst countries, for each subgroup, defined by cluster analysis, enabling each country, alongside the best globally, to retrieve the information from the best of its subgroups.

Paper [5] emphasizes that the DEA method is extremely suitable for assessment of traffic safety, because of its multicriteria and nonparametric characteristics. Particularly emphasizing that the power of the DEA method lies not in the fact of rating but in the comparison with the examples of best practice.

Table 1 lists studies in which DEA method is used for assessment of traffic safety. Table 1 gives basic information about the type of used DEA model, the number of variables, as well as the number of DMUs, whose safety is evaluated.

\begin{tabular}{|c|c|c|c|c|c|c|c|}
\hline Study & Country & Number of DMUs & $\begin{array}{l}\text { No of } \\
\text { inputs }\end{array}$ & $\begin{array}{c}\text { No of } \\
\text { outputs }\end{array}$ & Method & $\begin{array}{c}\text { Orientation } \\
\text { of the model }\end{array}$ & $\begin{array}{c}\text { Returns to } \\
\text { scale }\end{array}$ \\
\hline $\begin{array}{c}\text { Ganji \& Rassafi } \\
(2019)\end{array}$ & EU & 27 EU countries & 3 & 1 & DF-CEM-ERA & Output & CRS \\
\hline Fancelloa et al. (2013) & Italy & 8 Italian cities & 4 & 4 & DEA & Input & CRS/VRS \\
\hline Ulutas (2018) & Turkey & 22 Turkish airports & 1 & 4 & DEA & Input & CRS \\
\hline Mikšová et al. (2018) & $\begin{array}{c}\text { Czech } \\
\text { Republic }\end{array}$ & $\begin{array}{c}13 \text { regions of the Czech } \\
\text { Republic }\end{array}$ & 4 & 1 & $\begin{array}{c}\text { DEA and composite } \\
\text { indicators }\end{array}$ & Output & VRS \\
\hline $\begin{array}{c}\text { Egilmez \& McAvoyc } \\
(2013)\end{array}$ & USA & 50 US states & 7 & 1 & DEA & Input & VRS \\
\hline Shen et al. (2012) & EU & 27 EU countries & 3 & 1 & DEA & Output & CRS \\
\hline Rosić et al. (2015) & Serbia & 27 police stations in Serbia & 2 & 3 & DEA & Output & CRS \\
\hline
\end{tabular}

Table 1. Methods used for assessment of the safety/efficiency of the traffic in the world

\section{Methodology}

The CCR model, developed by Charnes, Cooper and Rhodes in [13], was used to assess traffic safety in F B\&H, RS, BD and EU countries. This model assumes Constant Returns to Scale (CRS). In most studies related to assessment of traffic safety (see overview in Table 1), the CCR model is probably the most widely known and most commonly used DEA model. For CCR DEA model used in this study, the number of traffic accidents and the number of died in traffic 
accidents, as undesired outputs, have been selected to be inputs, and both inputs (population number and number of registered vehicles) were selected as outputs, as suggested in [14]. Input oriented CCR-CRS model provides information on how much the number of traffic accidents and number of died could be reduced, under condition, that traffic safety is at the level of the best practice example, while keeping the same number of registered vehicles and the existing number of inhabitants [15]. According to reviewed literature [16, 17, 18, 19, 20], for assessment of traffic safety in this study, 4 variables have been used - total number of traffic accidents with injured persons and number of persons died, as input variables, and number of inhabitants and number of registered vehicles, as output variables. Total number of samples (DMUs) was 31. The analysis focused on the time period 2015-2016, and the data were collected from the referential sources as follows: Institute for Statistics of F B\&H [21], Institute of Statistics of Republika Srpska [22, 23, 24], Agency for Statistics of B\&H [25], B\&HAMK [26], The European Road Safety Observatory (ERSO) [27], Publications Office of the European Union [28]. Data averages were used, which in some cases led to the appearance of non-integer values.

\section{Analysis of results}

Before the analysis and interpretation of the results, it is necessary to emphasize that the DEA estimates the relative, not absolute or theoretical maximum efficiency of the DMU. DMUs rated 1 or $100 \%$ are said to be effective and the example of the best practices in the traffic safety management, while all other DMUs are said to be ineffective, and they have to improve in order to achieve level or performances of effective ones.

Table 2 shows the results of traffic safety efficiency analysis, obtained by the DEA method, for the analyzed DMUs and time period 2015-2016.

\begin{tabular}{|c|c|c|c|}
\hline No. & $\overline{D M U}$ & Score & Rank \\
\hline 9 & Denmark & 1 & 1 \\
\hline 11 & Finland & 1 & 1 \\
\hline 22 & Netherlands & 1 & 1 \\
\hline 30 & Sweden & 1 & 1 \\
\hline 31 & United Kingdom & 0,9596 & 5 \\
\hline 7 & Cyprus & 0,9085 & 6 \\
\hline 21 & Malta & 0,9030 & 7 \\
\hline 29 & Spain & 0,8317 & 8 \\
\hline 15 & Ireland & 0,8204 & 9 \\
\hline 24 & Poland & 0,7583 & 10 \\
\hline 12 & France & 0,7251 & 11 \\
\hline 23 & Germany & 0,7148 & 12 \\
\hline 19 & Luxembourg & 0,702 & 13 \\
\hline 16 & Italy & 0,6781 & 14 \\
\hline 13 & Greece & 0,6662 & 15 \\
\hline 27 & Slovakia & 0,6169 & 16 \\
\hline 4 & Austria & 0,5878 & 17 \\
\hline 10 & Estonia & 0,5464 & 18 \\
\hline 8 & Czech Republic & 0,5191 & 19 \\
\hline 20 & Hungary & 0,4996 & 20 \\
\hline 25 & Portugal & 0,4977 & 21 \\
\hline 6 & Bulgaria & 0,4950 & 22 \\
\hline 18 & Lithuania & 0,4703 & 23 \\
\hline 28 & Slovenia & 0,4601 & 24 \\
\hline 5 & Belgium & 0,4543 & 25 \\
\hline 14 & Croatia & 0,3921 & 26 \\
\hline 17 & Latvia & 0,373 & 27 \\
\hline 1 & $\begin{array}{c}\text { Federation of Bosnia and } \\
\text { Herzegovina }\end{array}$ & 0,3724 & 28 \\
\hline 26 & Romania & 0,3539 & 29 \\
\hline 3 & Brcko District & 0,2847 & 30 \\
\hline 2 & Republic of Srpska & 0,2778 & 31 \\
\hline
\end{tabular}

Table 2. Traffic safety efficiency for the period $2015-2016$ 
The average relative traffic safety efficiency is 0,641 or $64,1 \%$. From table 2 , it can be seen that 4 DMUs (Denmark, Finland, the Netherlands and Sweden) form the efficiency frontier and are said to be efficient DMUs, i.e. the countries with the highest level of traffic safety, or the examples of the best practices. The remaining 27 DMUs are inefficient and they have to improve their traffic safety in order to achieve $100 \%$ efficiency.

DEA analysis can identify the referential DMUs for each inefficient DMU. The number of appearances in the reference set (table 3 and table 4) can be interpreted as the "robustness" measure of the best practice examples. Thus, Sweden, Denmark, the Netherlands and Finland appeared as referent in 18, 17, 6 and 5 cases, respectively. The fact that efficient countries appeared several times in the reference set, states that they are indeed the examples of the best practices, and that they are not declared effective because of their specific values of some input or output.

\begin{tabular}{|c|c|}
\hline DMU & $\begin{array}{c}\text { Number of appearances in the } \\
\text { reference set }\end{array}$ \\
\hline Sweden & 18 \\
\hline Denmark & 17 \\
\hline Netherlands & 6 \\
\hline Finland & 5 \\
\hline
\end{tabular}

Table 3. Number of appearances in the reference set

\begin{tabular}{|c|c|c|c|c|c|c|c|}
\hline \multirow{2}{*}{$\begin{array}{c}\text { No. } \\
1\end{array}$} & \multirow{2}{*}{$\begin{array}{c}\text { DMU } \\
\text { F B\&H }\end{array}$} & \multicolumn{6}{|c|}{ References } \\
\hline & & Denmark & 0,244 & Sweden & 0,084 & & \\
\hline 2 & RS & Denmark & 0,188 & Sweden & 0,009 & & \\
\hline 3 & $\mathrm{BD}$ & Finland & 0,005 & & & & \\
\hline 4 & Austria & Sweden & 1,012 & & & & \\
\hline 5 & Belgium & Sweden & 1,176 & & & & \\
\hline 6 & Bulgaria & Denmark & 1,263 & & & & \\
\hline 7 & Cyprus & Denmark & 0,208 & & & & \\
\hline 8 & $\begin{array}{c}\text { Czech } \\
\text { Republic }\end{array}$ & Denmark & 0,076 & Finland & 0,186 & $\begin{array}{c}\text { Netherla } \\
\text { nds }\end{array}$ & 0,537 \\
\hline 9 & Denmark & Denmark & 1 & & & & \\
\hline 10 & Estonia & Denmark & 0,272 & & & & \\
\hline 11 & Finland & Finland & 1 & & & & \\
\hline 12 & France & Denmark & 8,401 & Finland & 3,222 & $\begin{array}{l}\text { Netherla } \\
\text { nds }\end{array}$ & 0,07 \\
\hline 13 & Greece & Denmark & 2,644 & & & & \\
\hline 14 & Croatia & Denmark & 0,361 & Sweden & 0,22 & & \\
\hline 15 & Ireland & Denmark & 0,386 & Sweden & 0,256 & & \\
\hline 16 & Italy & Netherlands & 0,535 & Sweden & 7,526 & & \\
\hline 17 & Latvia & Denmark & 0,275 & Sweden & 0,042 & & \\
\hline 18 & Lithuania & Denmark & 0,511 & & & & \\
\hline 19 & Luxembourg & Finland & 0,038 & $\begin{array}{c}\text { Netherlan } \\
\text { ds }\end{array}$ & 0,026 & & \\
\hline 20 & Hungary & Denmark & 1,14 & Sweden & 0,343 & & \\
\hline 21 & Malta & Sweden & 0,058 & & & & \\
\hline 22 & Netherlands & Netherlands & 1 & & & & \\
\hline 23 & Germany & Sweden & 9,006 & & & & \\
\hline 24 & Poland & Denmark & 8,81 & & & & \\
\hline 25 & Portugal & Sweden & 1,088 & & & & \\
\hline 26 & Romania & Denmark & 3,384 & Sweden & 0,06 & & \\
\hline 27 & Slovakia & Denmark & 0,829 & Sweden & 0,072 & & \\
\hline
\end{tabular}




\begin{tabular}{|l|c|c|c|c|c|c|c|}
\hline 28 & Slovenia & Netherlands & 0,013 & Sweden & 0,191 & & \\
\hline 29 & Spain & Sweden & 5,501 & & & \\
\hline 30 & Sweden & Sweden & 1 & & & \\
\hline 31 & $\begin{array}{c}\text { United } \\
\text { Kingdom }\end{array}$ & Sweden & 6,646 & & & \\
\hline
\end{tabular}

Table 4. Groups of reference DMUs with corresponding reference coefficients

The use of the values given in table 4 is shown on the F B\&H example. Referential DMUs for F B\&H are Denmark and Sweden. Using coefficients given in table 4, it can be calculated for how much the number of traffic accidents with injured persons can be reduced, if the F B\&H has a level of traffic safety at the level of the most efficient countries:

$$
\begin{aligned}
& F B i H(I) 1=0,244 \cdot \operatorname{Denmark}(I) 1+0,084 \cdot \text { Sweden }(I) 1 \\
& F B i H(I) 1=0,244 \cdot 2.867,5+0,084 \cdot 14.457,5=1.914,1
\end{aligned}
$$

F B\&H has potential to decrease number of traffic accidents with injured persons from 5.132 to $1.914,1$ or $62,75 \%$, by increasing traffic safety to the level of the most efficient countries. The same calculation and projection can be done for the second input - the number of persons died in traffic accidents:

$$
\begin{gathered}
F B i H(I) 2=0,244 \cdot \operatorname{Denmark}(I) 1+0,084 \cdot \operatorname{Sweden}(I) 1 \\
F B i H(I) 2=0,244 \cdot 194,5+0,084 \cdot 264,5=69,676
\end{gathered}
$$

F B\&H has potential to increase traffic safety to the level of the most efficient countries by reducing the number of persons died in traffic accidents from 187 to 69,6 or $62,75 \%$.

\begin{tabular}{|c|c|c|c|c|c|c|c|c|c|}
\hline \multirow[b]{2}{*}{ No. } & \multirow[b]{2}{*}{ DMU } & \multirow[b]{2}{*}{ Score } & \multirow[b]{2}{*}{ Rank } & \multicolumn{3}{|c|}{$\begin{array}{l}\text { (I)1 } \\
\text { Total number of traffic } \\
\text { accidents with injured } \\
\text { persons }\end{array}$} & \multicolumn{3}{|c|}{$\begin{array}{c}\text { (I)2 } \\
\text { Number of persons } \\
\text { died in traffic accidents }\end{array}$} \\
\hline & & & & Value & Projection & Diff. (\%) & Value & Projection & Diff. (\%) \\
\hline 1 & F B\&H & 0,3724 & 28 & $5.132,00$ & $1.911,30$ & $-62,75$ & 187,00 & 69,64 & $-62,75$ \\
\hline 2 & $\mathrm{RS}$ & 0,2778 & 31 & $2.419,00$ & 672,02 & $-72,21$ & 140,50 & 39,03 & $-72,21$ \\
\hline 3 & $\mathrm{BD}$ & 0,2847 & 30 & 137,00 & 39,02 & $-71,52$ & 6,00 & 1,71 & $-71,52$ \\
\hline 4 & Austria & 0,5878 & 17 & $38.213,00$ & $14.635,90$ & $-61,69$ & 455,50 & 267,77 & $-41,21$ \\
\hline 5 & Belgium & 0,4543 & 25 & $40.199,50$ & $16.998,70$ & $-57,71$ & 684,50 & 310,99 & $-54,56$ \\
\hline 6 & Bulgaria & 0,4950 & 22 & $7.315,00$ & $3.621,52$ & $-50,49$ & 708,00 & 245,65 & $-65,30$ \\
\hline 7 & Cyprus & 0,9085 & 6 & 655,00 & 595,12 & $-9,14$ & 51,50 & 40,37 & $-21,61$ \\
\hline 8 & Czech Republic & 0,5191 & 19 & $21.473,50$ & $11.147,10$ & $-48,08$ & 672,50 & 349,10 & $-48,08$ \\
\hline 9 & Denmark & 1 & 1 & $2.867,50$ & $2.867,50$ & 0 & 194,50 & 194,50 & 0 \\
\hline 10 & Estonia & 0,5464 & 18 & $1.429,50$ & 781,19 & $-45,35$ & $1.749,50$ & 52,99 & $-96,97$ \\
\hline 11 & Finland & 1 & 1 & $4.958,00$ & $4.958,00$ & 0 & 262,00 & 262,00 & 0 \\
\hline 12 & France & 0,7251 & 11 & $57.057,50$ & $41.375,50$ & $-27,48$ & $3.469,00$ & $2.515,56$ & $-27,48$ \\
\hline 13 & Greece & 0,6662 & 15 & $11.379,00$ & $7.581,19$ & $-33,37$ & 808,50 & 514,23 & $-36,39$ \\
\hline 14 & Croatia & 0,3921 & 26 & $10.747,50$ & $4.214,69$ & $-60,78$ & 327,50 & 128,43 & $-60,78$ \\
\hline 15 & Ireland & 0,8204 & 9 & $5.862,00$ & $4.809,62$ & $-17,95$ & 174,00 & 142,76 & $-17,95$ \\
\hline 16 & Italy & 0,6781 & 14 & $175.165,00$ & $118.792,00$ & $-32,18$ & $3.355,50$ & $2.275,61$ & $-32,18$ \\
\hline 17 & Latvia & 0,373 & 27 & $3.742,00$ & $1.399,13$ & $-62,61$ & 173,00 & 64,68 & $-62,61$ \\
\hline 18 & Lithuania & 0,4703 & 23 & $3.116,00$ & $1.465,66$ & $-52,96$ & 218,00 & 99,41 & $-54,39$ \\
\hline 19 & Luxembourg & 0,702 & 13 & 962,00 & 675,81 & $-29,75$ & 34,00 & 23,89 & $-29,75$ \\
\hline 20 & Hungary & 0,4996 & 20 & $16.480,00$ & $8.233,78$ & $-50,03$ & 625,50 & 312,51 & $-50,03$ \\
\hline 21 & Malta & 0,9030 & 7 & $1.402,00$ & 839,14 & $-40,14$ & 17,00 & 15,35 & $-9,69$ \\
\hline 22 & Netherlands & 1 & 1 & $18.636,00$ & $18.636,00$ & 0 & 532,00 & 532,00 & 0 \\
\hline 23 & Germany & 0,7148 & 12 & $306.902,00$ & $130.205,00$ & $-57,57$ & $3.332,50$ & $2.382,10$ & $-28,51$ \\
\hline 24 & Poland & 0,7583 & 10 & $33.315,50$ & $25.263,60$ & $-24,16$ & $2.982,00$ & $1.713,61$ & $-42,53$ \\
\hline
\end{tabular}

The same approach can be used to calculate the projections for the reduction of inputs for all other DMUs, as shown in Table 5 (Projection column). For efficient DMUs, this projection is equal to current inputs, meaning that efficient countries are not in a DMU set with a mixed inefficiency. 


\begin{tabular}{|l|l|l|l|l|l|l|l|l|l|}
\hline 25 & Portugal & 0,4977 & 21 & $32.127,00$ & $15.726,50$ & $-51,04$ & 578,00 & 287,72 & $-50,22$ \\
\hline 26 & Romania & 0,3539 & 29 & $29.847,50$ & $10.564,30$ & $-64,60$ & $1.904,00$ & 673,90 & $-64,60$ \\
\hline 27 & Slovakia & 0,6169 & 16 & $5.552,00$ & $3.425,54$ & $-38,30$ & 292,50 & 180,47 & $-38,30$ \\
\hline 28 & Slovenia & 0,4601 & 24 & $6.536,50$ & $3.007,56$ & $-53,98$ & 125,00 & 57,51 & $-53,98$ \\
\hline 29 & Spain & 0,8317 & 8 & $100.059,00$ & $79.535,00$ & $-20,51$ & $1.749,50$ & $1.455,09$ & $-16,82$ \\
\hline 30 & Sweden & 1 & 1 & $14.457,50$ & $14.457,50$ & 0 & 264,50 & 264,50 & 0 \\
\hline 31 & United Kingdom & 0,9596 & 5 & $144.525,00$ & $96.091,70$ & $-33,51$ & $1.832,00$ & $1.758,00$ & $-4,03$ \\
\hline
\end{tabular}

Table 5. Projection of the traffic safety indicators for all DMUs

By summation of values given in table 5, provided all DMUs are relatively efficient, it can be seen that total number of traffic accidents with injured persons, for all DMUs, is 1.102.670 and it has potential to decrease to 644.526,6. This would result in reduction of total number of traffic accidents with injured persons by $458.142,9$ or by $42 \%$ per year. Also, the total number of persons died in traffic accidents, for all DMUs, is $27.905,5$ and according to projections it has potential to decrease to $17.231,08$, which means a decrease of $10.674,42$ or $38 \%$ per year.

\section{Conclusion}

For the assessment of the traffic safety in F B\&H, in relation to the traffic safety in RS, BD and EU countries, DEA model with constant returns to scale (CCR model) was used. Generally, traffic safety is usually expressed in undesirable outputs or desirable inputs, so we adopted approach in which undesirable output is modeled as an input and the desired input as an output. Due to this approach, the focus of the analysis was on the inputs, which led to selection and use of input oriented CCR model. The main goal of the research was to assess potential for reduction of traffic accidents and deaths in case that traffic safety in F B\&H is at the level of the traffic safety of the best practice countries. Data quality, selection of the DEA model, number and selection of input and output variables, and other methodology topics were adopted after review of literature, available in international publications and scientific databases.

It can be concluded, according to the conducted analysis, that there is a significant difference in the efficiency or traffic safety among EU countries. The results of the analysis show that traffic safety in F B\&H is somewhat greater than in $\mathrm{RS}$ and $\mathrm{BD}$, however, in an analysis whose results are not presented in the paper, and in which $\mathrm{B} \& \mathrm{H}$ is considered as one DMU as a whole (F B\&H, RS and BD variables data were summed), B\&H was last ranked.

Related to the selected DEA model, results of the analysis, and advantage of the DEA method to estimate input/output projections that would lead inefficient DMUs to become efficient DMUs, it can be concluded that the number of traffic accidents and deaths in F B\&H can be reduced by $62.75 \%$, in RS by $72.22 \%$, while in BD by $71.52 \%$. Reported percentage reductions can result in 5.065 less number of traffic accidents, and 223 less deaths per year, expressed in absolute values at the B\&H level. At the level of all DMUs, the total number of traffic accidents can be reduced by $458.142,9$ or by $42 \%$, while the total number of deaths can be reduced by $10.674,42$ or $38 \%$ per year.

Analysis was conducted under assumption that all DMUs where homogeneous, which in some cases is incorrect. For example, transit countries have a higher percentage of vehicles, not registered in considered DMU, that significantly participate in traffic then non-transit countries. Because of this fact, conducted analysis can be somewhat discriminating against transit countries, so their efficiency or inefficiency should be observed with a certain reserve (eg. Germany). For complete and comprehensive analysis, a certain mileage indicator should be taken into account for foreign vehicles in each of the DMUs, as well as some other indicators such as vehicle type and age, belt usage, driver alcoholic/drug status, number of emergency calls and speed of responses, and number of other factors. There are number of studies in which above indicators were used, but the aim of this paper is to assess Bosnia and Herzegovina, F B\&H, RS and BD position, status and trends in the traffic safety compared to EU countries.

\section{References}

[1] World Health Organization (2015). Global status report on road safety, Available from: https://www.who.int/violence_injury_prevention/road_safety_status/2015/en/. Accessed: 2019-03-08

[2] Forum of European Road Safety Research Institutes \& European Conference of Transport Research Institutes (FERSI/ECTRI) (2009). The Sustainable Safety Approach to Road Transport and Mobility, Available from: https://www.ectri.org/Documents/Publications/Strategic-documents/The-sustainable-safety-approach-to-RoadTransport-and-Mobility_Final.pdf. Accessed: 2019-03-06

[3] European Transport Safety Council (ETSC) (2011). 2010 Road Safety Target Outcome: 100,000 fewer deaths since 2001, 5th Road Safety PIN Report. ETSC, Brussels. Available from: archive.etsc.eu/documents/ETSC_2011_PIN_Report.pdf. Accessed: 2019-03-06 
[4] Rosic, M.; Kukic, D. \& Bozovic. M. (2015). Primena analize obavijanja podataka (DEA) za ocenu rizika u bezbednosti saobraćaja, Bezbednost saobraćaja u lokalnoj zajednici - IV Međunarodna konferencija, 29-30. October 2015., Banja Luka, Bosnia \& Hercegovina

[5] Bastos, J. T.; Shen, Y.; Hermans, E.; Brijs; T., Wets, G. \& Ferraz, A. C. P. (2015.). Traffic fatality indicators in Brazil: State diagnosis based on data envelopment analysis research, Accident Analysis and Prevention, No. 81, pp. 61-73

[6] Bax, C.; Wesemann, P.; Gitelman, V.; Shen, Y.; Goldenbeld, C.; Hermans, E.; Doveh, E.; Hakkert, S.; Wegeman, F. \& Arts. L. (2012). Developing a Road Safety Index. Deliverable 4.9 of the EC FP7 project DaCoTA

[7] Azevedo P \& L Yeung (2011). Measuring efficiency of Brazilian courts with data envelopment analysis (DEA), IMA Journal of Management Mathematics, Vol. 22, No. 4, pp. 343-356

[8] Fancelloa, G.; Uccheddua, B. \& Faddaa P. (2013). The performance of an urban road system: an innovative approach using D.E.A. (Data Envelopment Analysis), Procedia - Social and Behavioral Sciences, Vol. 87, 2013, pp. 163 176, DOI: $10.1016 /$ j.sbspro.2013.10.601

[9] Ulutas, B. H. (2018). Efficiency analysis of airports in Turkey considering environmental effects, Central European Review of Economics and Management, Vol. 2, No. 1, 2018, pp. 65-78, ISSN 2543-9472, eISSN 2544-0365

[10] Mikšová, D.; Elgner, J.; Valach, O. \& Ambros, J. (2018). Rating road safety performance of Czech regions using composite indicators, Advances in Transportation Studies: an international Journal, Section B, No. 46, 2018, pp. 153-162, ISBN 978-88-255-1864-1, ISSN 1824-5463, DOI: 10.4399/97882551864111

[11] Egilmez, G. \& McAvoyc, D. (2013). Benchmarking road safety of U.S. states: A DEA-based Malmquist productivity index approach, Accident Analysis \& Prevention, Vol. 53, 2013, pp. 55-64, DOI: 10.1016/j.aap.2012.12.038

[12] Shen, Y.; Hermans, E.; Brijs, T.; Wets, G. \& Vanhoof, K. (2012). Road safety risk evaluation and target setting using data envelopment analysis and its extensions, Accident Analysis \& Prevention, Vol. 48, 2012, pp. 430-441, DOI: 10.1016/j.aap.2012.02.020

[13] Charnes, A.; Cooper, W. W. \& Rhodes, E. (1978). Measuring the efficiency of decision making units, European Journal of Operational Research, Vol. 2, No. 6, 1978, pp. 429-444, DOI: 10.1016/0377-2217(78) 90138-8

[14] Liu W. B.; Meng W.; Li X. X. \& Zhang D. Q. (2010). DEA models with undesirable inputs and outputs, Annals of Operations Research, Vol. 173, No. 1, pp. 177-194

[15] Dyckhoff H. \& Allen K. (2001). Measuring ecological efficiency with Data Envelopment Analysis (DEA), European Journal of Operational Research, Vol. 132, No. 2, pp. 312-325

[16] Dyson, R.; Allen, R.; Camanho, A.; Podinovski, V.; Sarrico, C. \& Shale, E. (2001). Pitfalls and protocols in DEA, European Journal of Operational Research, Vol. 132, No. 2, pp. 245-259

[17] Amirteimoori, A; Despotis, D. K. \& Kordrostami, S. (2014). Variables reduction in data envelopment analysis, Optimization, Vol. 65, No. 5, pp. 735-745

[18] Golany, B.A. \& Roll, Y., (1989). An application procedure for data envelopment analysis, Omega, Vol. 17, No. 3, pp. 237-250

[19] Cooper, W. W.; Seiford, L. M. \& Tone, K. (2007). Data envelopment analysis: a comprehensive text with models, applications, references and DEA-solver software, 2nd edition, Springer, ISBN: 9780387452838, New York

[20] Friedman, L. \& Sinuany-Stern, Z. (1998). Combining ranking scales and selecting variables in the DEA context: The case of industrial branches, Computers and Operations Research, Vol. 25, No. 9, pp. 781-791

[21] http://fzs.ba (2018). Institute for Statistics of F B\&H, Statistical Yearbook of the Federation of Bosnia and Herzegovina 2018, Accessed: 2019-02-28

[22] Institute of Statistics of Republika Srpska (2016), Statistical Yearbook of Republika Srpska 2016, Available from: www.rzs.rs.ba, Accessed: 2019-01-31.

[23] Institute of Statistics of Republika Srpska (2017). Institute of Statistics of Republika Srpska, Statistical Yearbook of Republika Srpska 2017, Available from: www.rzs.rs.ba, Accessed: 2019-01-31,

[24] www.rzs.rs.ba (2019). Institute of Statistics of Republika Srpska, Population estimate in Republika Srpska, Available from: http://www.rzs.rs.ba/front/article/2464/.left_mi=None\&add=None. Accessed: 2019-01-31

[25] Agency for Statistics of B\&H (2019), Available from: http://bhas.gov.ba/data/Publikacije/Bilteni/2019/BRC_00_2018_B6_0_BS.pdf, Accessed: 2019-02-28,

[26] B\&HAMK (2019), Available from: http://B\&Hamk.ba/assets/upload/Informacija_o_registrovanim_vozi.\%20godini\%20(mersiha)\%20(3).pdf. Accessed: 2019-01-31

[27] The European Road Safety Observatory - ERSO (2018). Annual Accident Report 2018, Available from: https://ec.europa.eu/transport/road_safety/sites/roadsafety/files/pdf/statistics/dacota/asr2018.pdf, Accessed: 201901-31

[28] Publications Office of the European Union (2018). EU Transport in figures - statistical pocketbook 2018, Available from: https://ec.europa.eu/transport/sites/transport/files/pocketbook2018.pdf. Accessed: 2019-01-31 